\title{
Effects of ascorbic acid supplementation on the performance of growing pullets
}

\author{
${ }^{1}$ R. A. Sobayo, ${ }^{2}$ E. B. Oguntona, ${ }^{2}$ O. A. Osinowo, ${ }^{2}$ D. Eruvbetine ., ${ }^{2}$ A. M. \\ Bamgbose, ${ }^{3}$ O.A. Adeyemi, ${ }^{1}$ A. Olomola, ${ }^{2}$ A.O Oso, and ${ }^{1}$ J..M. Usman. \\ 1 Federal College of Forestry, P.M.B 5054, Jericho, Ibadan, Nigeria \\ 2 Department of Animal Nutrition, College of Animal Science and Livestock Production, \\ University of Agriculture, Abeokuta,P.M.B 2040 Abeokuta, Nigeria. \\ 3 College of Animal Production, Olabisi Onabanjo University, Ayetoro Campus, Ayetoro, Nigeria.
}

\begin{abstract}
Two studies were conducted to evaluate the nutritional effects of supplementary ascorbic acid (AA) at levels of $0,100,200$, and $300 \mathrm{mg} / \mathrm{kg}$ in the diets of growing pullets reared at different seasons (dry season and rainy season). 240 eight weeks-old Harco pullet chicks were used in each trial, they were randomly assigned to each of the four dietary treatments in three replications of twenty chicks per replicate. Each trial lasted 12 weeks 184 days) during which data were collected and a $2 \times 4$ factorial arrangement was employed in the analysis of data collected. Both ascorbic acid and season significantly affected $(P<0.05)$ growth rate with better growth rate reported in the dry season. Body weights at first lay exhibited a linear reduction with increasing concentration of ascorbic acid $(P<0.05)$. Seasonal variation significantly affected $(P<0.05)$ age and egg weight at first lay with higher values obtained in the rainy season. The cost-benefit analysis of supplementary ascorbic acid in the diet of experimental birds revealed that inclusion of the graded levels of ascorbic acid increased the cost of feed in a linear fashion across the dietary treatments. At the growing stage, cost offeed per $\mathrm{kg}$ weight gain was found to be lowest in birds fed $0 \mathrm{mg} / \mathrm{kg} \mathrm{AA}$. It was evident that at the growing stage, optimum response occurred with supplementation of $300 \mathrm{mg} / \mathrm{kg} \mathrm{AA}$.
\end{abstract}

Keywords: Ascorbic acid, supplementation, performance, pullets.

\section{Introduction}

Ascorbic acid is a simple six-carbon compound found in considerable amounts in citrus fruits and green vegetables, with feedstuff used in zodern poultry diet formulation lacking the substance. Domestic fowls like most terrestrial vertebrates, possess the innate ability to synthesize ascorbic acid for normal growth and development. There is increasing evidence that a dietary requirement may exist under certain environmental and physiological stress conditions. Physiological stress is defined as the non - specific response to any external demand, which calls upon the bird to adapt to a new condition, (Selye, 1973). Under these conditions, ascorbic acid is involved in the synthesis of the central stress hormones (epinephrine and corticosterone). Both hormones are responsible for the mobilization of energy for the so called essential functions such as blood flow, heat dissipation, maintenance of body temperature, respiration etc. In modern poultry management, there are several such factors which influence poultry productivity. These are heat, cold, humidity, pathogen, nutrient imbalance; others are molting, debeaking, high growth rate, frequent entry of personnel into poultry houses (Njoku et al., 1992). It has been generally associated with decline in production and performance in poultry (Siegel, 1980). Studies 
investigating the potential of ascorbic acid supplementation to stimulate growth in poultry have produced inconsistent results (Pardue, 1983; Njoku, 1984). Briggs et ál. (1994) supplemented highly purified diets with $100 \mathrm{mg}$ $\mathrm{AA} / \mathrm{kg}$ of diet and noted improved growth rates. However, addition of AA to corn/soy based ration had no effect on growth. This experiment was conducted to evaluate the role of dietary ascorbic acid in improving the performance of growing pullets reared under normal tropical conditions.

\section{Materials and Methods}

\section{Experimental Location}

The two trials were carried out at the University of Agriculture, Abeokuta Teaching and Research Farm, Alabata, Abeokuta. Alabata $\left(7^{\circ} 10^{\circ}\right.$ and $3^{\circ}$ $2^{\circ} \mathrm{E}$ ) is located in the tropical sub- savannah region with an average ambient temperature of $33^{\circ}$, a relative humidity of $80 \%$ and a mean precipitation of $1100 \mathrm{~mm}$ per annum.

\section{Experimental Design}

Thestudy was designed to have two trials (I and II), which were carried out on the use of graded levels of ascorbic acid at different seasons. Trial I was carried out in the rainy season (MayAugust) while trial II was carried out in the dry season (November-January). Experimental birds in each trial were randomly allotted to the dietary treatments in three replications of twenty chicks per replicate.

\section{Experimental Treatments}

The feed ingredients used for the preparation of basal diet were purchased from UNAAB Consult feedmill, Kotopo, Abeokuta, while the feed grade ascorbic acid used was sourced from Nutrivitas Nigeria Limited, Lagos. There were four experimental treatments, made up of the basal diet which served as the control, while diets two, three and four contained 100, 200 and $300 \mathrm{mg}$ added ascorbic acid per $\mathrm{kg}$ of the basal diet (Table 1):

\section{Experimental Birds}

A total of two hundred and forty 8 weeks old Harco pullet chicks were used in the study. Sixty (60) chicks were randomly assigned to one of the four dietary treatments in three replications of twenty chicks per replicate. The birds were raised on deep litter pens with dry wood shavings as litter material. At 16 weeks of age the birds were transferred from the deep litter system to a 960 - bird capacity standard Petersime battery cage with automatic nipple drinkers. The cage as well as the house was thoroughly disinfected prior to transfer. The birds were vaccinated against the major poultry diseases endemic in the area. Feed and water were given ad libitum throughout the period. The birds were weighed at the beginning of the trials and weekly thereafter. Feed intake was measured daily with feed: gain determined by dividing it with average weight gain. Age at first egg was determined by the number of days after hatching when the first egg was laid and 5 birds per replicate randomly weighed and the body weight taken as the body weight at first egg.

\section{Chemical and Statistical analyses}

The proximate composition of the diet was determined by the AOAC (1995). The results of the parameters were subjected to $2 \mathrm{X} 4$ factorial analysis. The analysis of variance was done according to the procedure of the Statistical Analysis System (SAS, 2001).

\section{Results}

The results of the main effects of dietary ascorbic acid levels and season on average final weight (AFW), average weight gain (AWG), feed intake (F. I), feed: gain ratio (F: $G$ ), \% mortality and cost 
Table 1 Percentage compositions of experimental basal diets (growers mash)

Level of Ascorbic Acid (mg/kg) supplementation

\begin{tabular}{lcccc}
\cline { 2 - 5 } Ingredient & $\mathbf{0}$ & $\mathbf{1 0 0}$ & $\mathbf{2 0 0}$ & $\mathbf{3 0 0}$ \\
\hline Maize & 35.00 & 35.00 & 35.00 & 35.00 \\
Soya bean Meal & 5.30 & 5.30 & 5.30 & 5.30 \\
Groundnut Cake & 6.00 & 6.00 & 6.00 & 6.00 \\
Wheat Offal & 24.00 & 24.00 & 24.00 & 24.00 \\
Brewers Dried Grain & 25.00 & 25.00 & 25.00 & 25.00 \\
Bone Meal & 2.00 & 2.00 & 2.00 & 2.00 \\
Oyster Shell & 2.00 & 2.00 & 2.00 & 2.00 \\
*Vit/Trace Min. Premix & 0.25 & 025 & 0.25 & 0.25 \\
Salt & 0.25 & 0.25 & 0.25 & 0.25 \\
Methonine & 0.10 & 0.10 & 0.10 & 0.10 \\
Lysine & 0.10 & 0.10 & 0.10 & 0.10 \\
Vitamin C & & & ++ & +++ \\
& 100.00 & 100.00 & 100.00 & 100.00 \\
Calculated Analyses & & & & \\
Crude Protein (\%) & 16.23 & 16.23 & 16.23 & 16.23 \\
Ether Extract (\%) & 4.26 & 4.26 & 4.26 & 4.26 \\
Crude Fibre (\%) & 6.31 & 6.31 & 6.31 & 6.31 \\
Calcium (\%) & 1.36 & 1.36 & 1.36. & 1.36 \\
Phosphorus (\%) & 0.45 & 0.45 & 0.45 & 0.45 \\
M.E (Kca/kg-1) & 2411.00 & 2411.00 & 2411.00 & 2411.00 \\
& & & & \\
Determined Analyses & & 14.03 & 14.03 & 14.03 \\
Crude Protein (\%) & 14.03 & 7.79 & 7.79 & 7.79 \\
Crude Fibre (\%) & 7.79 & 3.25 & 3.25 & 3.25 \\
Ether Extract (\%) & 3.25 & & & \\
\hline & & & & \\
\end{tabular}

* Provided the following per $\mathrm{kg}$ of feed:

* * Grower Premix

Vit. $A=4,000,000$ iu; Vit. $D_{3}=800,000$ iu; Vit. $E=10,000 \mathrm{mg}$,Vit. $K_{3}=1,200 \mathrm{mg}$; Vit. $B_{1}=1,000 \mathrm{mg}$; Vit. $B_{2}=1,500 \mathrm{~m}$, Vt $\mathrm{B}_{6}=, 500 \mathrm{mg}$; Niacin $=10,000 \mathrm{mg}$; Panthothenate $=4,500 \mathrm{mg}$, Biotin $=15 \mathrm{mg} ;$ Vit $B_{12}=10 \mathrm{mg} ;$ Folic Acid $=200 \mathrm{mg}$, Chlorine chloride $=120,000 ;$ Manganese $=60,000 \mathrm{mg}$, Iron $=15,000 \mathrm{mg} ;$ Zinc $=15,000 \mathrm{mg} ;$ Copper $=800 \mathrm{mg}$, lodine $=400 \mathrm{mg}$; Cobalt $=$
$80 \mathrm{mg}$ Selenium $=40 \mathrm{mg}$ 
benefit analysis of growing pullets are presented in Table 2. Significant differences $(P<0.05)$ were shown in weight gain and feed: gain ratio due to varying levels of ascorbic acid (AA). The highest average final weight of $1059.24 \mathrm{~g}$ was observed in $300 \mathrm{mg} \mathrm{AA} / \mathrm{kg}$, which had the highest daily feed intake of $80.61 \mathrm{~g}$. Percent mortality was found to increase steadily across the dietary treatments with increasing levels of AA with the highest value of $6.04 \%$ recorded in birds fed $300 \mathrm{mg} \mathrm{AA} /$ $\mathrm{kg}$. General comparison of the dietary treatments across the season they were fed revealed significant differences $(P<0.05)$ in all the parameters measured. Birds fed graded levels of ascorbic acid during the hotter period gave better AFW, AWG, ADG and F: G ratio than birds in the rainy season. Nevertheless, higher feed intake was observed in the rainy compared to the dry period. Interaction effects of different levels of AA $X$ season indicated significant differences $(\mathrm{P}<0.05)$ for average weight gain and average daily weight gain as presented in Table 3. Lower values of average weight gain (AWG) were obtained in the rainy season when graded levels of AA were fed compared to the dry season where $300 \mathrm{mg} / \mathrm{kg} \mathrm{AA}$ gave the highest weight gain value of $826.67 \mathrm{~g}$. The interaction of AAX season revealed a value of $10.41 \%$ mortality when 300 $\mathrm{mg}$ of the substance per $\mathrm{kg}$ was fed in the dry as compared to $1.67 \%$ recorded in the rain. At this stage of birds' growth, birds fed $0 \mathrm{mg} \mathrm{AA} / \mathrm{kg}$ gave the lowest feed cost per $\mathrm{kg}$ weight gain, with the highest value of $\mathrm{N} 213.02$ recorded in $200 \mathrm{mg} \mathrm{AA} / \mathrm{kg}$. The cost of feed per $\mathrm{kg}$, however, ranged between $N 20.68$ and $N 21.22$. Effects of ascorbic acid levels and season and their interaction on age, body and egg weights at first lay are presented in Table 4 and Table 5 respectively. Analysis of variance indicated significant differences $(\mathrm{P}<0.05)$ in body weight due to graded levels of AA and the season had significant effect on age at first egg and egg weight. Birds fed $200 \mathrm{mg} / \mathrm{kg}$ added AA were the first to come into lay with an average egg weight of $42.05 \mathrm{~g}$. Body weights of bird at first lay, however, decreased across the dietary treatments from $1450.7 \mathrm{~g}$ in $0 \mathrm{mg} \mathrm{AA} / \mathrm{kg}$ to $1323.80 \mathrm{~g}$ in 300 mg AA $/ \mathrm{kg}$. Furthermore, age and egg weights at first lay indicated slightly lower values in the dry season compared to rainy season. Mean egg weight ranged from $42.05-44.05 \mathrm{~g}$ among the dietary treatments with the highest value of egg weight occurring in birds fed $100 \mathrm{mg} \mathrm{AA} / \mathrm{kg}$. Interaction effects of different $A A$ levels and season generated no significant difference $(\mathrm{P}>0.05)$ in the parameters measured. However, values of age and egg weight at first lay were found to be higher in the rainy season with graded levels of AA fed.

\section{Discussion}

Studies investigating the potential of ascorbic acid supplementation to stimulate growth in poultry have produced inconsistent results (Pardue, 1983). Although, there were significant effects in the AWG and ADG, birds on $0 \mathrm{mg} \mathrm{AA}$ $\mathrm{kg}$ gave better growth. This result agrees with earlier work of Pardue (1983) in which he reported an absence of growth stimulation in birds fed 250,500 or $1000 \mathrm{mg} / \mathrm{kg}$ supplemental AA. Aiso, consistent with this finding was the failure of dietary AA in stimulating improved growth in birds fed practical diet (Fratzer et al., 1996) but there was a response with a purified diet and perhaps, the birds on this diet could be considered to be under some form of nutritional stress. Feed intake was not significantly affected by dietary treatments. However; significantly lower feed intake value was exhibited at the dry period of this phase. Furthermore, the significant effect of dietary AA on feed: gain ratio agrees with the earlier finding of Njoku (1986) who reported significant effects in feed conversion efficiency following ascorbic acid 


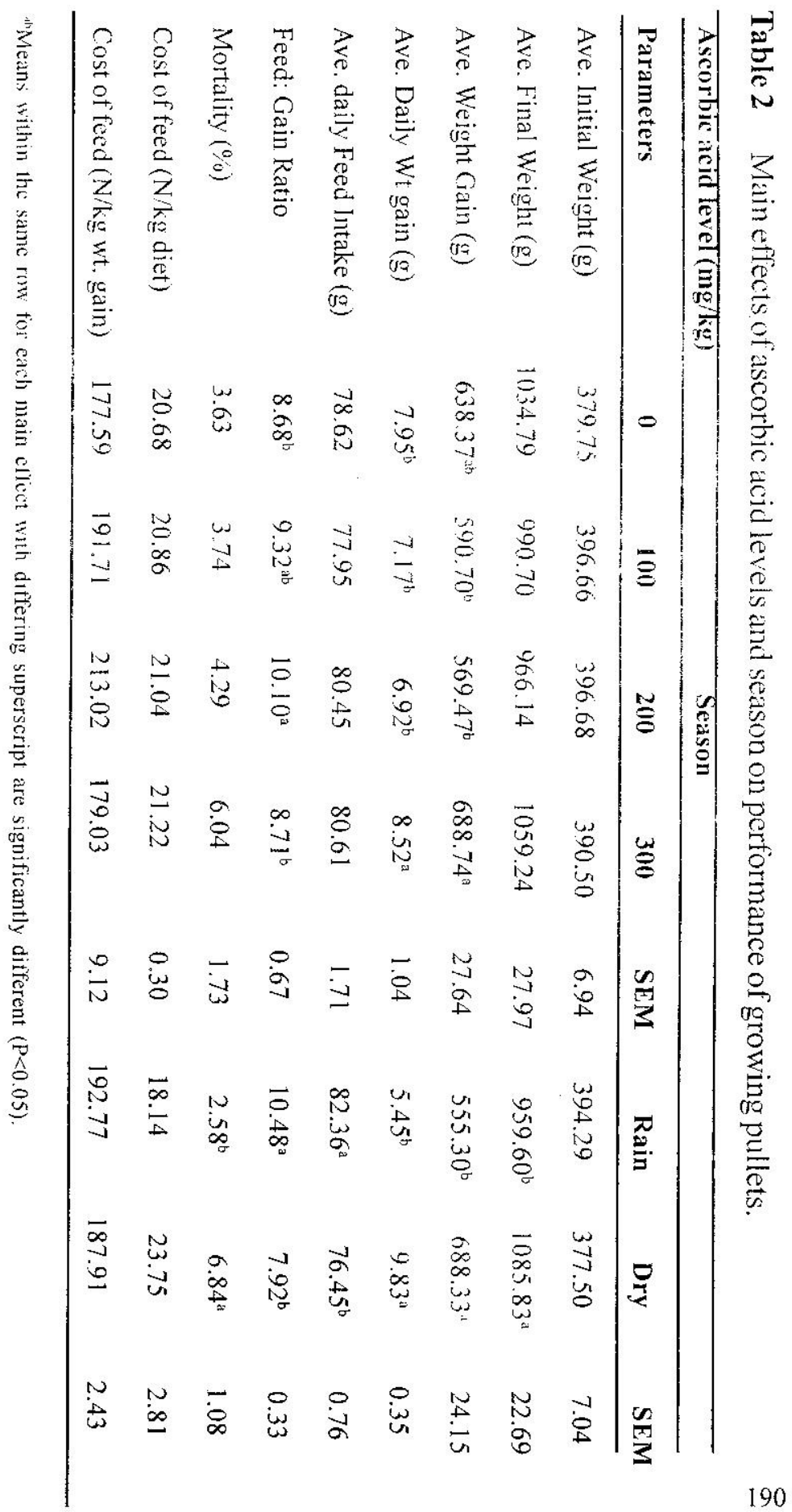




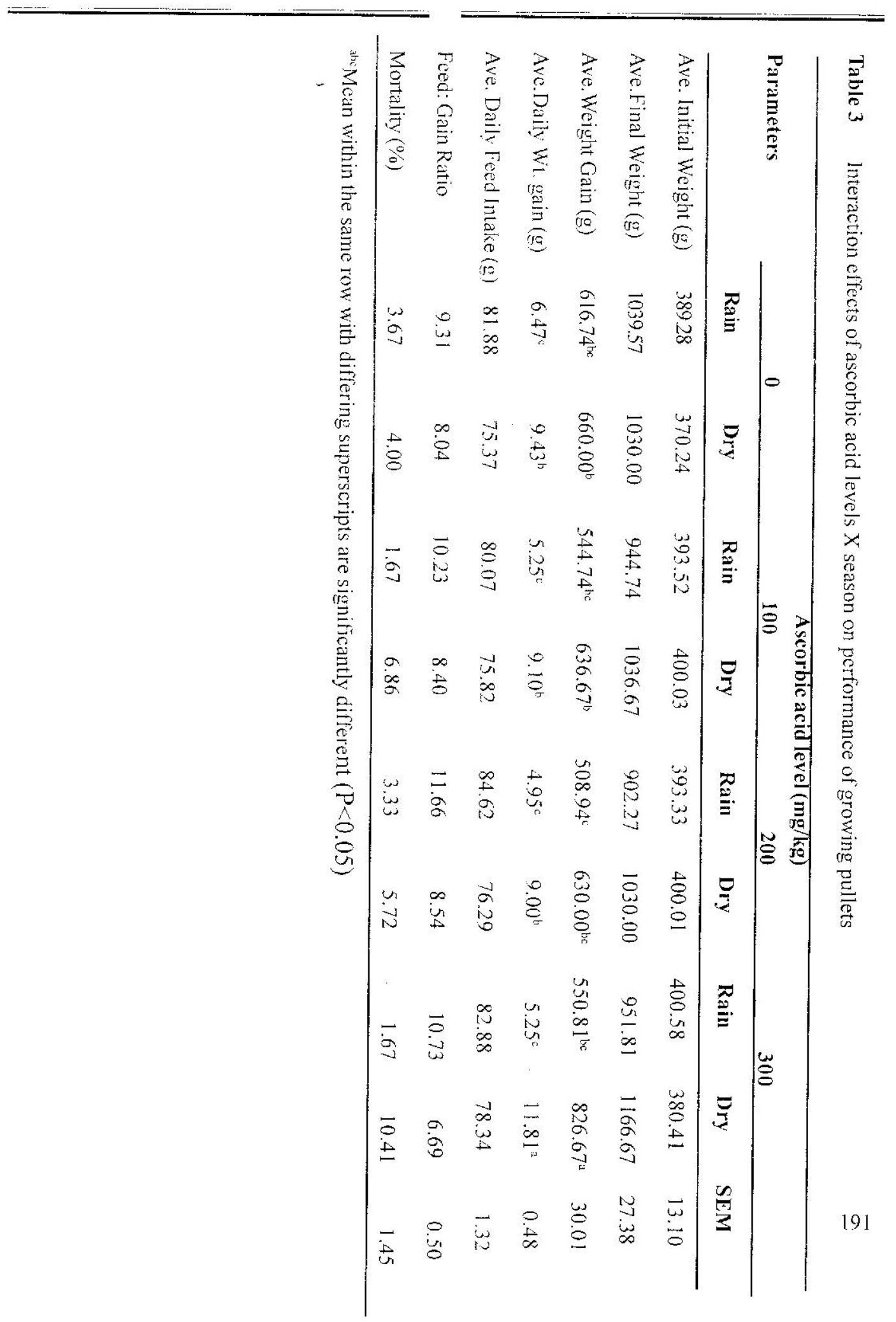




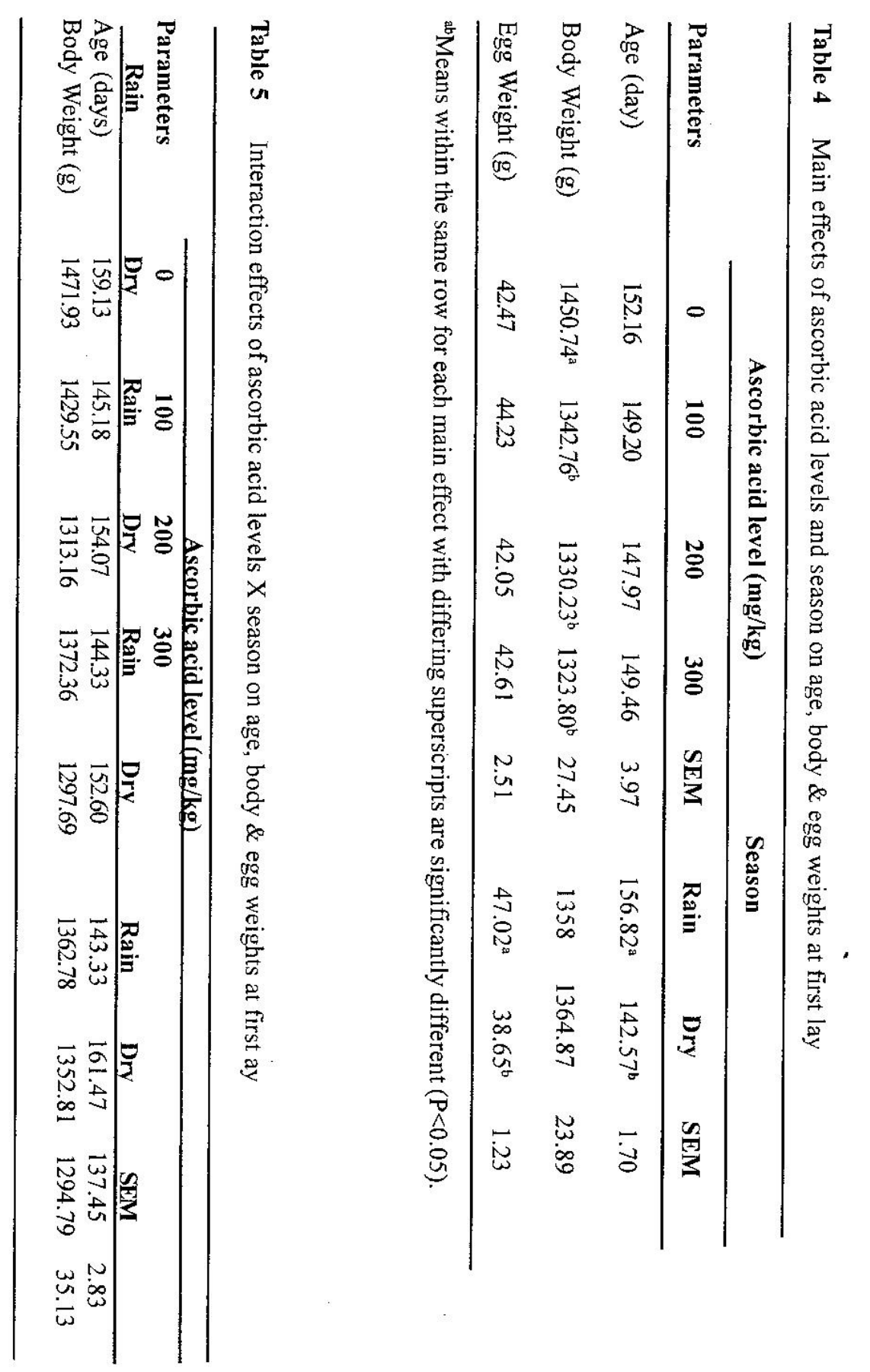


supplementation. At this stage of birds' development, the graded levels of AA supplementation did not significantly affect percent mortality and in fact, birds fed graded levels of supplemental AA/ $\mathrm{kg}$ exhibited higher $\%$ mortality compared to the control group. This result is, however, in agreement with the previous work of Kassab et al. (1990). The significant greater improvement in performance parameter shown in the dry period of the grower phase might be as a result of higher environmental conditions characteristic of the late dry season with an average temperature of $24.5 \mathrm{C}$ and a linear relationship has been established between ascorbic acid and high environmental temperature. Thus, the result agrees with the earlier work of Kazzim and Norziha (1995). The workers reported that addition of AA to diets improved body weight and feed efficiency in birds reared under hot $(20-35 \mathrm{C})$ and humid conditions in Malaysia. The pattern of cost of feed per kilogram weight gain at the grower stage recorded in the study might be due to the fact that quantifying the cost of feed in relation to weight gain may not be economically justified as cost differential among the dietary treatments was not all that pronounced. There were no significant advantages obtained in age at first lay and egg weight due to dietary treatments. Nevertheless, birds with supplemental AA came into lay earlier than those on $0 \mathrm{mg} \mathrm{AA} / \mathrm{kg}$. Body weights at first lay were found to be significantly different and birds on $0 \mathrm{mg} / \mathrm{kg} \mathrm{AA}$, however, gave higher body weight of $8.17 \%$ over AA treated birds at first lay. Seasonal significant effects were noticed in age and egg weight at first lay. Birds reared during the dry period were the first to come into lay. The reason might have been due to the higher sunlight intensity (lightning) associated with the period, which has been found to affect the development of the ovary, and the lower egg weight of the dry period might be attributed to lower feed intake with resultant lower nutrient ingestion which is found to affect egg size.

\section{References}

A. O. A. C. 1995. Official methods of analysis $16^{\text {th }}$ edition. Association of Official Analytical Chemists, Washington D. C.

Briggs G. M., Jr. Luckey, T. D., Elvehjem C. A. and Hart E. B. 1944. Effect of ascorbic acid on chick growth when added to purified rations. Proceedings of the Society of Experimental Biology and Medicine 55: 130.

Fratzer, F. H., Alinquist, H. J. and Vohra, P. 1996. Effect of diet on growth and plasma ascorbic acid in chicks. Poultry Science, 75: 82-89.

Kassab, A., Al-Senied, A. A. and Injidi, M. H. 1990. Effect of dietary ascorbic acid on the physiology and performance of heat - stressed broiler chicken. Proc. of the $2^{\text {nd }}$ symposium, Kartanse Ittingen, Switzerland $9^{\text {th }}-12^{\text {th }}$ October, 1990.

Kassim, H. and Norziha, I. 1995. Effects of ascorbic acid (vitamin C) supplementation in layer and broiler diets in the tropics. AsianAustralasian Journal of Animal Science 8: 607610 .

Njoku, P. C. 1984. The Effect of ascorbic acid supplementation on broiler performance in a tropical environment. Poultry Science, 63 (Suppl. 1): 156 .

Njoku, P. C. 1986. Effect of dietary ascorbic acid (Vitamin C) supplementation on the performance of broiler chickens in a tropical environment. Anim. Feed Sci. Tech. 16, 17-24. 
Njoku, P. C., C. D. Tuleun, S. O. Ogundipe, T. F. Balogun and S. A. S. Olorunju. 1992. Ascorbic acid. A Paper Presented at the $17^{\text {th }}$ Annual Conference of the Nigerian Society for Animal Production (NSAP) held at Abuja Sheraton Hotel and Towers, 23rd-27th March, 1992.

Pardue, S. L. 1983 Relationship of ascorbic acid to physiological stress in the domestic fowl. Ph.D Dissertation, North Carolina State University, Raleigh, N. C.
SAS Institute 2001. SAS/ STAT. guide for personal computer, version 8 edition (Cary, North Carolina SAS Institute).

Selye, H. 1973. The evolution of the stress concept. Animal Science, 61:692-695.

Siegel, W. S. 1980. Physiological Stress in birds. Bioscience, 30, 529 - 534 .

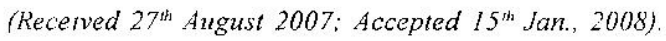

